\title{
Sağlık Hizmetleri Meslek Yüksekokulu Son Sınıf Öğrencilerinin İş Bulma Endişeleri ve Umutsuzluk Düzeyleri
}

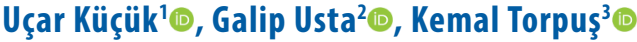

${ }^{1}$ Artvin Çoruh Üniversitesi, Sağlık Hizmetleri MYO, İlk ve Acil Yardım, Artvin, Türkiye

${ }^{2}$ Trabzon Üniversitesi, Tonya MY0, İlk ve Acil Yardım Programı, Trabzon, Türkiye

${ }^{3}$ Artvin Çoruh Üniversitesi, Sivil Savunma ve Itfaiyecelik, Artvin, Türkiye

Uçar Küçük, Öğr. Gör. Galip Usta, Öğr. Gör. Kemal Torpuş, Öğr. Gör.

Iletişim:

Öğr. Gör. Uçar Küçük

Artvin Çoruh Üniversitesi, Sağık Hizmetleri MY0, Illk ve Acil Yardım, Artvin, Türkiye

Tel: +90 $4662151082 / 6052$

E-Posta: ucr@artvin.edu.tr

Gönderilme Tarihi : 03 Ağustos 2017

Revizyon Tarihi : 14 Kasım 2017

Kabul Tarihi : : 21 Kasım 2017
ÖZET

Amaç: Bu araştırmanın amacı Sağlık Hizmetleri Meslek Yüksekokulu son sınıf öğrencilerinin iş bulma endişelerini, etkileyen faktörleri ve umutsuzluk düzeylerini belirlemek amacıyla yapılmıştır.

Yöntem: Araştırmanın örneklemini Artvin Çoruh Üniversitesi Sağlık Hizmetleri Meslek Yüksekokulunda okuyan son sınıf öğrencileri oluşturmaktadır. Çalışmaya dahil edilen 230 öğrenciye tanıtıc özelliklerini belirleyen anket formu ve Beck Umutsuzluk Ölçeği uygulanmıştır. Verilerin değerlendirilmesinde SPSS 16.0 paket programı kullanılmıştır. Veriler sayı ve yüzde şeklinde ifade edilmiştir. Sayısal verilerin değerlendirilmesinde T-testi ve Anova kullanıImıştır.

Bulgular: Öğrencilerin \% 40'ı ilk ve acil yardım, \%33,5'i çocuk gelişimi, \%11,7'si eczane hizmetleri ve \%14,8'i yaşlı bakımı programı öğrencisidir. Program seçim kararııı kendisi vermiş, 24 yaş ve üzerinde olan iş bulma süresinin 6 aydan kısa olacağını ifade eden öğrencilerin toplam umutsuzluk puanlarının anlamlı derecede düşük olduğu bulunmuștur. Katılımcıların $\% 45,7$ 'si öğrenim gördüğü programın, idealindeki program olduğu, $\% 63,5^{\prime}$ i programa ilgi duyduğu ve $\% 25,2^{\prime}$ si de diploma sahibi olmak için tercih ettiğini belirtmiştir.

Sonuç: Son sınıf öğrencilerinin iş bulmaya yönelik umutsuzluk düzeylerinin bazı değişkenlere göre anlamlı derecede farklılık gösterdiği bulunmuştur. Umutsuzluk puanlarının programlar arasında farkılığa yol açmadığı görülmektedir. Cinsiyet faktörünün ve öğrencilerin barındığı yerlerin toplam umutsuzluk puanına anlamlı şekilde etki etmediği görüşmüştür. Öğrencilerin tahmini iş bulacaklarını düşündükleri süre uzadıkça toplam umutsuzluk puanlarında da artış olduğu görülmüştür.

Anahtar sözcükler: Iş bulma kaygısı, umutsuzluk, son sınıf öğrencileri

EMPLOYMENT CONCERNS AND DESPAIR LEVELS OF VOCATIONAL SCHOOL OF HEALTH SERVICES' FINAL YEAR STUDENTS ABSTRACT

Purpose: The objective of this research is to determine the employment concerns, affecting factors and levels of despair of vocational school of health services' final year students.

Methods: The sample of the research consists of final year students studying at Artvin Çoruh University Vocational School of Health Services. A survey form defining the descriptive characteristics and the Beck Hopelessness Scale were applied to 230 students included in the study. The SPSS 16.0 package program was used to evaluate the data. The data are expressed in numbers and percentages. T-Test and ANOVA were used in the evaluation of numerical data.

Results: $40 \%$ of the students are primary and emergency help students, $33.5 \%$ are child development, $11.7 \%$ are pharmacy services and $14.8 \%$ are old-school program students. It has been found that the total hopelessness scores of students, aged 24 or older who chose the program on their own, are significantly low in students who stated that they would find a job in a period shorter than 6 months, who had no concerns about employment and whose education type is an evening education. It has been found that $45.7 \%$ of the participants preferred this program because it was their ideal program; $63.5 \%$ said that they were interested in the program and $25.2 \%$ preferred it (in order) to have a diploma.

Conclusion: It has been found that the level of hopelessness of final year students about finding a job differs significantly according to some parameters. It has been seen that hopelessness scores do not lead to differences between programs. The gender factor and place of stay have not changed the overall hopelessness score significantly. When the estimated time that students think they will get a job gets longer, the total hopelessness score increases.

Keywords: Student, hopelessness, finding job 
şsizlik, potansiyel istihdam yetkinliğine sahip bireylerin iş bulamadığında ortaya çıkan bir durum olarak tanımlanmaktadır. İşsizlik verilerine bakılarak ülkelerin ekonomik durumları hakkında yorum yapılabilir. Bu nedenle genellikle ekonomik durumun bir ölçüsü olarak da kullanılmaktadır (1).

International Labour Organization (ILO) raporuna göre küresel işsizlik oranının 2017'de \%5,7'den \%5,8'e yükselmesi beklenirken global işsizlik oranının 2018 yılında nispeten istikrarlı seyretmesi beklenmektedir $(2,3)$. Türkiye İstatistik Kurumu Mart 2017 raporuna göre işsizlik oranı ülkemizde \%11.7 olarak belirlenmiştir. Aynı raporda yer alan istidam oranına bakıldığında istihdam edilenlerin sayısı 2017 yılı mart döneminde, bir önceki yılın mart dönemine göre 496 bin kişi artarak 27 milyon 489 bin kişiye ulaştığı bulunmuş, istidam oranında ise herhangi bir değişiklik olmayarak \%46.1 seviyesinde kaldığı belirtilmiştir. 2016 - 2017 yılları arasında 15 ve daha yukarı yaşlardaki işsiz sayısı 619 bin artarak 3 milyon 642 bin olarak tespit edilmiştir (4).

İşsizlik ekonomik problemin yanında küresel, toplumsal ve kişisel sonuçları beraberinde getiren bir durumdur. Aynı zamanda işsizlik kaygısı bireylerde korku, ümitsizlik, mutsuzluk, kendini değersiz görme gibi etmenleri doğururken fiziksel ve ruhsal problemlere de yol açmaktadır (5).

Bir olay karşısında beklentilerin gerçekleşmediği, sorunların çözümsüz kaldığı, kişinin ulaşmak istediği hedeflere ulaşamadığını düşündüğü durumlara ümitsizlik denilmiştir $(5,6)$. Diğer yandan ümitsizlik/umutsuzluk 1986'da hemşirelik tanısı olarak da onaylanmış ve NANDA (Kuzey Amerikan Hemşirelik Tanıları Birliği) tarafından "Bireyin sınırlı ya da hiç alternatif veya kişisel seçim olanağı bulamadığı ve kendi enerjisini harekete geçiremediği subjektif bir durum" olarak tanımlanmıştır $(7,8)$. Türk Dil Kurumu ise umut sözcüğünü "Ummaktan doğan güven duygusu, ümit" veya "Bu duyguyu veren kimse veya şey" olarak tanımlamaktadır $(9,10)$. Ümit ve Ümitsizlik kişinin geleceğe bakışını değiştiren gelecekteki hedeflerine odaklanmasında rol oynayan önemli faktörlerdendir. Genel olarak bakıldığında sosyal ve ekonomik durumların üniversite çağında olan gençlerin ruhsal gelişimlerini ve ruh sağlığını yakından etkilediği görülmektedir (12). Son yıllarda sağlık hizmetleri meslek yüksekokullarında öğrenci kontenjanlarının artması ve işe alımların azalması öğrencilerin iş bulma kaygısını artırmaktadır.

Araştırma Artvin Çoruh Üniversitesi SağlıkHizmetleri Meslek Yüksekokulu son sınıf öğrencilerinin iş bulma endişeleri ile umutsuzluk düzeylerinin belirlemek ve planlı istihdam noktasında literatüre katkı sağlamak amacıyla yapılmıştır.

\section{Gereç ve yöntem}

Araştırma Artvin Çoruh Üniversitesi Sağlık hizmetleri meslek yüksekokulu son sınıf öğrencilerine yapılan tanımlayıcı tipte bir çalışmadır. Araştırmanın evrenini SHMYO'da öğrenim gören 317 son sınıf öğrencisi oluşturmaktadır. Yapılan çalışmada örneklem seçimi yapılmamış olup evrenin tamamı araştırmaya alınmıştır. Okula kayıtlı olduğu halde gelmeyen ve/veya düzenli bir şekilde eğitime devam etmeyen 87 öğrenci çıkartılmış, sürekli devam eden 230 öğrenci araştırmaya katılmıştır.

Araştırmada veri toplama aracı olarak anket formu ve Beck Umutsuzluk Ölçeği (BUÖ) kullanılmıştır. Araştırmada kullanılan anket formu öğrencilerin kişisel bilgilerini ve sosyodemografik özelliklerini sorgulayan sorulardan oluşmaktadır. Anket formu öğrencilerin cinsiyeti, yaşı, öğrenim gördükleri programı, eğitim şekli, kaldıkları yer, program tercih kararı, iş bulma süreleri ve endişeleri, programı tercih etme nedenleri ve mezun olduklarında ne yapmayı düşündüklerini inceleyen sorulardan oluşmaktadır. Diğer veri toplama aracımız olan BUÖ, Beck ve arkadaşları tarafından (1974) geliştirilmiş 20 maddelik kendini değerlendirme türü bir ölçektir. Bu çalışmayla öğrencilerin geleceğe yönelik karamsarlık derecesinin belirlenmesi planlanmaktadır. BUÖ'nde sorular duygusal, motivasyonel ve bilişsel durumları ölçen ana başlıklarından oluşur. Katılımcılardan sorulan sorulara evet ya da hayır cevabı vermeleri istenir. Sorulardan "1, 3, 5, 6, 8, 10, 13, 15, 19. sorularda "hayır"; 2, 4, 7, 9, 11, 12, 14, $16,17,18,20$. sorulara ise "evet" yanıtı için 1 puan verilir. Katılımcıların alacağı minimum puan 0 , maksimum puan 20 'dir. Alınan puanların yüksek olması genel bakış açımızdaki gibi olumlu yöne gidişatı değil umutsuzluğa yönelimin yüksek olduğunu gösterir. Elde edilen toplam puan umutsuzluk puanı olarak kabul edilmektedir.

Araştırma verileri, 29 Mayıs-7 Haziran 2017 tarihleri arasında hazırlanan anket formlarının öğrenciler tarafından doldurulması ile elde edilmiştir. Araştırma için Artvin Yerel Etik Kurulu'ndan 18.05.2017 tarihinde etik kurul izni alınmıştır. Katılımcılara çalışmanın amacı ve önemi hakkında bilgi verilerek araştırmaya katılma onamları sözlü olarak alınmıştır.

Tüm veriler SPSS 16.0 paket programı kullanılarak çözümlendi. Veriler sayı ve yüzde şeklinde ifade edildi. Sayısal verilerin karşılaştııılmasında T-testi ve Anova kullanıldı. Tüm analizler için anlamlılık düzeyi $p<0,05$ olarak kabul edilmiştir. 


\section{Bulgular}

Çalışmamıza son sınıfta okuyan 230 öğrenci katılmıştır. Bunların \%40'ı (n:92) ilk ve acil yardım (53'ü örgün öğretim, 39'u İkinci öğretim), \%33,5'i (n:77) çocuk gelişimi (44'ü örgün öğretim, 33'u ikinci öğretim), \%11,7'si eczane hizmetleri ve \%14,8'i yaşlı bakım programı öğrencisidir. Yaşlı bakımı programının 2. Sınıf ikinci Öğretimi ve eczane hizmetleri programının ikinci Öğretim kısmı bulunmadığı için öğrenci sayıları diğerlerine göre daha azdır.

Tablo 1'e göre umutsuzluk puanı en yüksek olan yaşlı bakımı programı, en düşük olan çocuk gelişimi programı öğrencileri olarak görülmektedir. Fakat öğrencilerin okudukları programlar arasında toplam umutsuzluk puanları incelendiğinde istatistiksel olarak anlamlı derecede farklılık yoktur. Cinsiyetlere göre baktığımızda erkeklerin umutsuzluk puanı daha yüksek gözükse de aralarında anlamlı bir ilişki yoktur.

Yaş grupları incelendiğinde toplam umutsuzluk puan değerleri açısından istatistiksel olarak anlamlı derecede farklılık olduğu bulunmuştur. 24 ve üzeri yaş grubu bireylerde 19 ve altı, 20-21, 22-23 yaş bireylere göre toplam umutsuzluk puanlarının anlamlı derecede düşük olduğu bulunmuştur. ( $p<0,05$, Tablo 2$)$.

Öğrencilerin kaldıkları yerler ve toplam umutsuzluk puanları karşılaştıııldığında aralarında istatistiksel olarak anlamlı derecede farklılık bulunmamıştır. Aile/akraba yanında kalan bireylerde evde, devlet yurdunda ve özel yurtta kalan bireylere göre toplam umutsuzluk puanlarının düşük olduğu görülmektedir. Devlet yurdunda kalan bireylerde evde, özel yurtta ve aile/akraba yanında kalanlara göre umutsuzluk puanlarının yüksek olduğu görülmekte$\operatorname{dir}(p>0,05$, Tablo 2).

Mezuniyet sonrası iş bulma süreleri ve toplam umutsuzluk puanları karşılaştıııldığında aralarında istatistiksel olarak anlamlı derecede farklılık olduğu belirlenmiştir. Tahmini iş bulma süresinin 6 aydan kısa süreceğini düşünen öğrencilerin toplam umutsuzluk puanının, iş bulma sürelerini 6-11 ay, 12-23 ay, 24-35 ay ve 36 ay ve üzeri olarak düşünen öğrencilere göre anlamlı derecede düşük olduğu görülmüştür. Gruplar arasında en yüksek umutsuzluk puanına sahip olanlar, iş bulma süresini 36 ay ve üzerinde tahmin edenler olmuştur ( $p<0,05$, Tablo 2 ).

Öğrencilerin iş bulma endişesi ve umutsuzluk puanları karşılaştırıldığında aralarında istatistiksel olarak anlamlı derecede farklılık olduğu belirlenmiştir. İş bulma endişesi olmayan bireylerde toplam umutsuzluk puanlarının iş bulma endişesi olanlar ve kısmen olanlara göre anlamlı derecede düşük olduğu görülmüştür ( $p<0,05$, Tablo 2 ).

Tablo 1. Öğrencilerin okuduğu program ve cinsiyetleri arasında toplam umutsuzluk puanı dağılımı

\begin{tabular}{lcccc} 
& & $\boldsymbol{n}$ & $\%$ & $\begin{array}{c}\text { Umutsuzluk puanı } \\
\boldsymbol{X} \pm \text { SS }\end{array}$ \\
\hline Program & İlk ve Acil Yardım & 92 & 40,0 & $5,55 \pm 4,56$ \\
Oneway ANOVA & Çocuk Gelişimi & 77 & 33,5 & $4,81 \pm 3,71$ \\
p:0,108 & Eczacılık Hizmetleri & 27 & 11,7 & $5,62 \pm 4,30$ \\
& Yaşı Bakımı & 34 & 14,8 & $6,97 \pm 4,30$ \\
Cinsiyet & Kadın & 168 & 73,0 & $5,29 \pm 4,31$ \\
T Testi p:0,170 & Erkek & 62 & 27,0 & $6,16 \pm 4,06$
\end{tabular}

Tablo 2. Toplam umutsuzluk puanını etkileyen faktörler ve puan dağıımı

\begin{tabular}{|c|c|c|c|c|}
\hline $\begin{array}{l}\text { Toplam umutsuzluk } \\
\text { faktörünü etkileyen } \\
\text { durumlar }\end{array}$ & & $n$ & $\%$ & $\begin{array}{l}\text { Umutsuzluk } \\
\text { puanı } X \pm S S\end{array}$ \\
\hline \multirow{4}{*}{$\begin{array}{l}\text { Yaş } \\
\text { Oneway ANOVA } \\
p: 0,34\end{array}$} & 19 ve altı & 20 & 8,7 & $5,60 \pm 4,73$ \\
\hline & $20-21$ & 153 & 66,5 & $5,04 \pm 4,23$ \\
\hline & $22-23$ & 49 & 21,3 & $7,08 \pm 3,83$ \\
\hline & 24 ve üzeri & 8 & 3,5 & $5,00 \pm 4,27$ \\
\hline \multirow{4}{*}{$\begin{array}{l}\text { Kalınan yer } \\
\text { Oneway ANOVA } \\
\text { p:0,217 }\end{array}$} & Ev & 81 & 35,2 & $5,51 \pm 4,44$ \\
\hline & Devlet Yurdu & 86 & 37,4 & $6,12 \pm 4,37$ \\
\hline & Özel Yurt & 53 & 23,0 & $4,86 \pm 3,83$ \\
\hline & Aile/Akraba Yanı & 10 & 4,3 & $3,90 \pm 3,31$ \\
\hline \multirow{3}{*}{$\begin{array}{l}\text { Program seçim kararını } \\
\text { kimin verdiği } \\
\text { Oneway ANOVA } \\
\text { p:0,03 }\end{array}$} & Kendim & 198 & 86,1 & $5,14 \pm 4,06$ \\
\hline & Ailem & 22 & 9,6 & $8,00 \pm 5,02$ \\
\hline & Başkaları & 10 & 4,3 & $7,70 \pm 4,05$ \\
\hline \multirow{5}{*}{$\begin{array}{l}\text { Öğrencinin tahmini iş } \\
\text { bulmayı düşündüğü süre } \\
\text { Oneway ANOVA } \\
\text { p:0,00 }\end{array}$} & 6 aydan kısa & 69 & 30,0 & $4,18 \pm 3,41$ \\
\hline & $6-11$ ay & 62 & 27,0 & $4,74 \pm 3,64$ \\
\hline & $12-23$ ay & 41 & 17,8 & $6,17 \pm 5,15$ \\
\hline & 24-35 ay & 23 & 10,0 & $6,86 \pm 4,58$ \\
\hline & 36 ay ve üzeri & 35 & 15,2 & $7,91 \pm 4,18$ \\
\hline \multirow{3}{*}{$\begin{array}{l}\text { Öğrencinin iş bulma } \\
\text { endişesi } \\
\text { Oneway ANOVA } \\
\text { p:0,00 }\end{array}$} & Var & 111 & 48,3 & $6,76 \pm 4,38$ \\
\hline & Yok & 46 & 20,0 & $4,34 \pm 3,47$ \\
\hline & Kısmen & 73 & 31,7 & $4,38 \pm 4,01$ \\
\hline \multirow{2}{*}{$\begin{array}{l}\text { Eğitim şekli } \\
\text { T Testi p:0,035 }\end{array}$} & Örgün öğretim & 158 & 68,7 & $5,92 \pm 4,28$ \\
\hline & 2. öğretim & 72 & 31,3 & $4,65 \pm 4,08$ \\
\hline
\end{tabular}

Öğrencilerin örgün ve ikinci öğretim olma durumları ile toplam umutsuzluk puanları karşılaştırıldığında aralarında istatistiksel olarak anlamlı derecede farklılık olduğu belirlenmiştir. İkinci öğretimde okuyan bireylerde toplam umutsuzluk puanlarının örgün öğretimde okuyan bireylere göre anlamlı derecede düşük olduğu görülmüştür $(p<0,05$, Tablo 2). 
Okudukları programı idealindeki program olarak belirtenlerin, idealindeki program olarak belirtmeyenlere göre toplam umutsuzluk puanı istatistiksel olarak anlamlı şekilde düşük bulunmuştur. Programa ilgi duyan bireylerde duymayanlara göre toplam umutsuzluk puanı istatistiksel olarak anlamlı şekilde düşük bulunmuştur ( $\mathrm{p}<0,05$, Tablo 3).

Tablo 3. Öğrencilerin programları tercih etme nedenleri ve BUÖ puan dağllımı

\begin{tabular}{|c|c|c|c|c|}
\hline $\begin{array}{l}\text { Öğrencilerin programları } \\
\text { tercih etme nedenleri }\end{array}$ & & $n$ & \multicolumn{2}{|c|}{ Umutsuzluk puanı } \\
\hline \multirow{3}{*}{$\begin{array}{l}\text { İdealimdeki program } \\
\text { olduğu için tercih ettim } \\
\text { p:0,037 }\end{array}$} & Evet & 105 & 45,7 & $4,77 \pm 4,17$ \\
\hline & Hayır & 58 & 25,2 & $6,44 \pm 4,26$ \\
\hline & Kısmen & 67 & 29,1 & $5,91 \pm 4,23$ \\
\hline \multirow{3}{*}{$\begin{array}{l}\text { Bu program ilgi duyduğum } \\
\text { için tercih ettim } \\
\text { p:0,05 }\end{array}$} & Evet & 146 & 63,5 & $4,87 \pm 4,14$ \\
\hline & Hayır & 45 & 19,6 & $7,13 \pm 4,45$ \\
\hline & Kısmen & 39 & 17,0 & $6,10 \pm 3,95$ \\
\hline \multirow{3}{*}{$\begin{array}{l}\text { Hemen ataması yapılan bir } \\
\text { program olduğu için tercih } \\
\text { ettim } \\
\text { p:0,057 }\end{array}$} & Evet & 90 & 39,1 & $6,31 \pm 4,02$ \\
\hline & Hayır & 78 & 33,9 & $5,28 \pm 4,58$ \\
\hline & Kısmen & 62 & 27,0 & $4,69 \pm 4,01$ \\
\hline \multirow{3}{*}{$\begin{array}{l}\text { Aldığım puan bu programa } \\
\text { yettiği için tercih ettim } \\
\text { p:0,063 }\end{array}$} & Evet & 81 & 35,2 & $6,40 \pm 4,03$ \\
\hline & Hayır & 90 & 39,1 & $4,93 \pm 4,43$ \\
\hline & Kısmen & 59 & 25,7 & $5,22 \pm 4,13$ \\
\hline \multirow{3}{*}{$\begin{array}{l}\text { Diploma sahibi olmak için bu } \\
\text { programı tercih ettim } \\
\text { p:0,02 }\end{array}$} & Evet & 58 & 25,2 & $6,93 \pm 3,75$ \\
\hline & Hayır & 128 & 55,7 & $4,67 \pm 4,22$ \\
\hline & Kısmen & 44 & 19,1 & $6,13 \pm 4,45$ \\
\hline
\end{tabular}

Okuduğum programı sadece diploma sahibi olmak için tercih ettim diyenlerin toplam umutsuzluk puanı diğer gruplara göre anlamlı biçimde yüksek bulunmuştur $(p<0,05$, Tablo 3).

Öğrencilerin mezuniyet sonrası ne yapmak istiyorsunuz bölümünde; dikey sınavı ile lisans tamamlamak istiyorum, kamu personeli seçme sınavına hazırlanmak istiyorum, başka bir bölüm/program okumak istiyorum, mezun olduğum alanda iş bulup çalışmak istiyorum, alanımda iş bulana kadar beklemek istiyorum sorularına verilen cevaplar arasında toplam umutsuzluk puanı açıdan anlamlı fark bulunmamıştır ( $p>0,05$, Tablo 4). Aynı kategoride yer alan "Ne iş bulursam yaparım" sorusuna verilen cevaplar değerlendirildiğinde öğrencilerin toplam umutsuzluk puanlarında istatistiksel olarak anlamlı derecede farklılık tespit edilmiştir. Ne iş bulursam yapmam diyen bireylerin yaparım diyen bireylere göre toplam umutsuzluk puanının anlamlı derecede yüksek olduğu belirlenmiştir ( $p<0,05$, Tablo 4).
Tablo 4. Öğrencilerin mezuniyet sonrası yapmayı düşündükleri durumlar ve BUÖ puan dağılımı

\begin{tabular}{|c|c|c|c|c|}
\hline $\begin{array}{l}\text { Öğrencilerin mezuniyet } \\
\text { sonrası yapmak istedikleri } \\
\text { Analiz için T-Testi } \\
\text { kullanılmıştır }\end{array}$ & & $n$ & $\%$ & $\begin{array}{l}\text { Umutsuzluk } \\
\text { puanı } X \pm S S\end{array}$ \\
\hline \multirow{2}{*}{$\begin{array}{l}\text { DGS ile lisans tamamlamak } \\
\text { istiyorum } \\
\mathrm{p}: 0,712\end{array}$} & Evet & 168 & 73,0 & $5,58 \pm 4,34$ \\
\hline & Hayır & 62 & 27,0 & $5,35 \pm 4,03$ \\
\hline \multirow{2}{*}{$\begin{array}{l}\text { KPSS için hazırlanmak } \\
\text { istiyorum } \\
\mathrm{p}: 0,705\end{array}$} & Evet & 184 & 80,0 & $5,47 \pm 4,36$ \\
\hline & Hayır & 46 & 20,0 & $5,73 \pm 3,84$ \\
\hline \multirow{2}{*}{$\begin{array}{l}\text { Başka bir bölüm/program } \\
\text { okumak istiyorum } \\
\text { p:0,07 }\end{array}$} & Evet & 95 & 41,3 & $6,43 \pm 4,40$ \\
\hline & Hayır & 135 & 58,7 & $4,88 \pm 4,04$ \\
\hline \multirow{2}{*}{$\begin{array}{l}\text { Mezun olduğum alanda iş } \\
\text { bulup çalışmak istiyorum } \\
\text { p: } 0,233\end{array}$} & Evet & 172 & 74,8 & $5,33 \pm 4,23$ \\
\hline & Hayır & 58 & 25,2 & $6,10 \pm 4,28$ \\
\hline \multirow{2}{*}{$\begin{array}{l}\text { Ne iş bulursam yaparım } \\
\text { p: } 0,00\end{array}$} & Evet & 36 & 15,7 & $7,91 \pm 4,35$ \\
\hline & Hayır & 194 & 84,3 & $5,08 \pm 4,09$ \\
\hline \multirow{2}{*}{$\begin{array}{l}\text { Alanımla ilgili iş bulana } \\
\text { kadar beklemek istiyorum } \\
\mathrm{p}: 0,334\end{array}$} & Evet & 77 & 33,5 & $5,90 \pm 4,70$ \\
\hline & Hayır & 153 & 66,5 & $5,33 \pm 4,01$ \\
\hline
\end{tabular}

\section{Tartışma}

Üniversitede bölüm veya program seçimi mezuniyetten sonra iş bulma noktasında farklıklara neden olmaktadır. Bizim yaptığımız araştırmada umutsuzluk puanlarının programlar arasında farklılığa yol açmadığı görülmektedir. Toplam umutsuzluk puanı en yüksek olan yaşıı bakımı programı iken en düşük puana sahip olan ise çocuk gelişimi programıdır. Çocuk gelişimi programında okuyan öğrencilerin toplam umutsuzluk puanının düşük çıkmasının nedeni programın istihdam alanlarının geniş olmasından kaynaklandığı düşünülmektedir. Yaşı bakımı programı öğrencilerinin toplam umutsuzluk puanının yüksek çıkmasının nedenleri olarak programın yeni açılmış olması ve istihdam alanlarının belirsiz olmasından kaynaklandığı düşünülmektedir. Yaptığımız çalışmaya benzer olarak Dereli ve Kabataş'ın Sağlık Yüksekokulu (SYO)'nda yaptığı çalışmada da bölümler arasında umutsuzluk puanları açısından farklılık bulunmamıştır (13).

Çalışmamızda cinsiyet faktörü ile umutsuzluk puanı arasında istatistiksel açıdan anlamlı fark olmadığı görülmektedir. Erkek $(6,16)$ öğrencilerin umutsuzluk puanının kız $(5,29)$ öğrencilerin umutsuzluk puanından yüksek olduğu görülmüştür. Ceyhan'ın öğretmen adayları üzerinde yaptığı çalışmada (erkek:9,96 kız:7,38), Aktağ ve Alpay'ın Beden Eğitimi ve Spor Yüksekokulu'nda yaptığı çalışmada (erkek:4,81 kız:3,76), Aydın ve arkadaşlarının SYO ve Sağlık Meslek Lisesi (SML)'nde yaptığı çalışmada 
(erkek:6,2 kız:5,4) da benzer sonuçlara rastlanmıştır. Yapılan çalışmaların sonuçlarına göre cinsiyet faktörü ile umutsuzluk puanı arasında arasın da anlamlı bir fark vardır $(5,15,16)$. Yapılan buna benzer diğer çalışmalar bu bulguları destekler niteliktedir $(13,17,18)$. Çalışmalarda erkeklerin, kadınlara oranla umutsuzluk puanlarının yüksek olduğu tespit edilmiştir. Türkiye İstatistik Kurumu iş istatistikleri Mart 2017 sayısında erkekler arasında işsizlik oranının yüzde 9,3'ten 10,5'e (2016'dan 2017'ye), kadınlar arasındaki oranın yüzde 11,8'den 14,3'e çıktığı görülmüştür. Genç işsizlik oranı ise erkeklerde yüzde 19,3'e, kadınlarda yüzde 25 'e çıkmıştır (4). Burada kadınlarda işsizlik oranının yüksek çıkmasının nedeninin kadınların çalışmamayı tercih etmelerinden ya da çalışabilecekleri bir iş bulamamalarından kaynaklı olduğu düşünülebilir. Her iki cinste de işsizliğin artmasına karşın bizim çalışmamızda ve yapılan benzer çalışmalarda erkeklerin işsizlik konusunda umutsuzluk puanlarının yüksek olmasının nedeni toplumda ve iş hayatında erkeklerin rolünden kaynaklandığı düşünülmektedir. Şahin'in de çalışmasında belirttiği gibi erkekler, geleneksel rolleri gereği ailenin geçimini sağlamak durumundadırlar. Erkeğe yüklenen bu sorumluluk üniversitede öğrenim gören erkek öğrencilerin kız öğrencilere göre daha fazla iş bulma kaygısı yaşamalarına yol açmaktadır (19).

Yaş grupları karşılaştııılığında toplam umutsuzluk puan değerleri açısından istatistiksel olarak anlamlı derecede farklııık görülmektedir. Araştırmada 24 ve üzeri yaş grubu bireylerde toplam umutsuzluk puanlarının en düşük, 2223 yaş grubu bireylerde toplam umutsuzluk puanlarının en yüksek olduğu görülmektedir. Üstün ve arkadaşlarının yaptığı çalışmada yaş ile öğrencilerin umutsuzluk puanları arasında anlamlı bir ilişki olduğunu göstermiş ve çalışmamızı destekler niteliktedir. Fakat Üstün ve arkadaşlarının çalışmasında yaşla beraber kaygının da arttığı görülürken bizim çalışmamızda aralarında böyle bir ilişki yoktur (7).

Öğrencilerin kaldıkları yerler ve toplam umutsuzluk puanları karşılaştıııldığında aralarında istatistiksel olarak anlamlı derecede farklılık görülmemiştir. Çalışmamızda devlet yurdunda kalanlarda $(6,12 \pm 4,37)$ en yüksek, aile/ akraba yanında kalanlarda en düşük $(3,90 \pm 3,31)$ toplam umutsuzluk puanı görülmektedir. Ailesinin yanında kalan öğrencilerin sosyal ve psikolojik desteğinin daha iyi olması beklenmektedir. Alınan sosyal ve psikolojik destek bireylerin sağlıklı davranışlarının sürekliliğinin sağlanması açısından önemlidir. Üstün ve arkadaşlarının yaptığı çalışmada kalınan yer ile toplam umutsuzluk puanları arasında anlamlı bir fark bulunmuştur. Aile yanında kalan öğrencilerin evde ya da devlet yurdunda kalan öğrencilere göre toplam umutsuzluk puanlarının anlamlı derecede düşük olduğu görülmüştür. Üstün ve arkadaşlarının yaptığı çalışmadaki veriler çalışmamızdaki verilerle örtüşmektedir (7).

Mezuniyet sonrası tahmini iş bulma süreleri ve toplam umutsuzluk puanları karşılaştırıldığında, aralarında istatistiksel olarak anlamlı derecede farklılık görülmektedir. Çalışmamızda tahmini iş bulma süresini 6 aydan kısa olacağını düşünen öğrencilerin toplam umutsuzluk puanının düşük olduğu görülmektedir. İş bulma süresinin daha uzun olacağını düşünen öğrencilerde umutsuzluk puanının arttığı görülmüştür.. Üstün ve arkadaşlarının yaptığı çalışmada ise iş bulma süresi 6 aydan kısa olanlarda toplam umutsuzluk puanı en düşüktür ve bu sonuç diğer gruplara göre anlamlı bulunmuştur (7). Bizim çalışmamızın aksine Dereli ve Kabataş 6 aydan kısa sürede iş bulabileceğini düşünen öğrencilerin diğer gruplara göre daha umutsuz olduğunu belirlenmiştir. Bu durumu öğrencilerin 6 aydan daha kısa sürede iş bulmak istemelerine rağmen, sürenin uzaması düşüncesi ya da iş bulamama endişeleri nedeniyle umutsuzluk puanlarının diğer gruplara göre daha fazla olduğu ile açıklanabilir şeklinde ifade etmiştir (13). Bu sonuç, öğrencilerin daha kısa sürede iş bulacaklarını düşündüklerinden işsizlik kaygısını daha az yaşadıklarını düşündürmektedir.

Öğrencilerin toplam umutsuzluk puanına bakıldığında okuduğu program seçim kararını kendim verdim diyenlerin $(5,14 \pm 4,06)$, kararı ailem verdi diyenlerden $(8,00 \pm 5,02)$ ve kararı başkaları verdi diyenlerden $(7,70 \pm 4,05)$ daha düşük olduğu tespit edilmiştir. Üstün ve arkadaşlarının yaptığı çalışmada okudukları programı isteyerek seçmeyenlerde, isteyerek seçenlere göre toplam umutsuzluk puanının anlamlı derecede yüksek olduğu görülmektedir (7). Dereli ve Kabataş ile Aytaç ve Bayram'ın yaptıkları çalışmada ise aile yönlendirmesi ile meslek seçimini yapanların iş bulma kaygısı yaşanmadıkları görülmüştür $(21,13)$. Bizim çalışmamızda ise meslek seçimini ailesi yapanların en yüksek umutsuzluk puanına sahip olduğu görülmüştür. Ailelerin program seçim kararına ortak olmasının öğrenciler üzerine baskı oluşturduğu düşünülmektedir.

İş bulma endişesi olanların toplam umutsuzluk puanı, iş bulma endişesi olmayan ya da kısmen olanlardan anlamlı derecede daha yüksek bulunmuştur. Aydın ve arkadaşlarının SYO ve SML öğrencilerinde yaptığı çalışmada iş bulma endişesi olan öğrencilerin daha umutsuz oldukları saptanmıştır (5). Sağlıkla ilgili okullarda ki öğrenci kontenjanlarının artışı ve mezun sayılarına rağmen yeteri kadar istihdamın sağlanamaması beraberinde rekabeti 
ve işsizliği getirmektedir. Mezunların iş bulma endişesi umutsuzluğa yol açmakta, umutsuzluk ise depresyon gibi psikiyatrik bozukluklara neden olabilmektedir (11). Dereli ve Kabataşın çalışmasında, SYO öğrencilerinin yarısından fazlasının iş bulma endişesi yaşadığı, iş bulma endişesi yaşayan öğrencilerin de daha umutsuz oldukları saptanmıştır ve bulgularımızı desteklemektedir (13).

\section{Sonuç ve öneriler}

Program seçim kararının mezuniyet sonrası iş bulma durumunda önemli rol oynadığı görülmektedir. Çalışma alanları geniş olan bir bölüm/programda okuyanların

\section{Kaynaklar}

1. İnvestopedia. İşsizlik, http://www.investopedia.com/terms/u/ unemployment.asp, Erişim: 21.05.2019.

2. İO. World Employment Social Outlook, http://www.ilo.org/wcmsp5/ groups/public/---dgreports/---dcomm/---publ/documents/ publication/wcms_541211.pdf, Erişim: 21.05.2019.

3. NBS. Global Unemployment Rate To Rise In 2017 http://www. premiumtimesng.com/news/more-news/220418-globalunemployment-rate-rise-2017-report.html, Erişim: 21.05.2019.

4. TÜiK. www.tuik.gov.tr/PreHaberBultenleri.do?id=24628, Erişim: 29.05.2019.

5. Aydın M, Erdoğan S, Yurdakul M, Eker A. Sağlık yüksekokulu ve sağlık meslek lisesi öğrencilerinin umutsuzluk düzeyleri. SDÜ Sağlık Bilimleri Dergisi 2013; 4:1-6.

6. NHT. Nanda Hemşirelik Tanıları, http://kadinvehastaliklari.com/ umitsizlik-hemsirelik-bakimi/ Erişim: 21.05.2019.

7. Üstün G, Dedekoç Ş, Kavalalı T, Öztürk F, Sapcı Y, Can S. Üniversite Son Sınıf Öğrencilerinin İş Bulmaya ilişkin Umutsuzluk Düzeylerinin İncelenmesi. Amasya Üniversitesi Eğitim Fakültesi Dergisi, 2014;3:200-21.

8. MDT. Umutsuzluk, http://medical-dictionary.thefreedictionary.com/ hopelessness, Erişim: 21.05.2019

9. TDK. http://www.tdk.gov.tr/index.php?option=com gts\&arama=gts\&guid=TDK.GTS.596c9457c20473.53519588, Erişim: 21.05.2019.

10. TB Ümitsizlik, https://www.turkcebilgi.com/\%C3\%BCmit_etmek, Erişim: 21.05.2019.

11. Dilbaz N, Seber G. Umutsuzluk Kavramı: Depresyon ve İntiharda Önemi. Kriz Dergisi 2003;1:134-8.

12. Yalçın, S, Açıkgöz İ. Sağlık Bilimleri Fakültesi Son Sınıf Öğrencilerinin Umutsuzluk Düzeylerinin Karşılaştırılması. Mustafa Kemal Üniversitesi Sosyal Bilimler Enstitüsü Dergisi, 2014; 11:259-70. geleceğe bakışlarının daha umut dolu olduğu tespit edilmiştir. Öğrencilerin mezun olduktan sonra iş bulmayı düşündükleri süre uzadıkça umutsuzluk durumları da aynı derede artış göstermektedir. Ailelerin program seçim kararında etkili olması ve öğrencilerin okudukları programı kendi istekleriyle seçmemeleri umutsuzluk oranlarını artırmaktadır.

Geleceğimiz olan gençlerimizin geleceğe daha umutlu bakabilmeleri için okuyacakları programı kendilerinin seçmesine olanak sağlanmalıdır. Tercih aşamasında doğru rehberlik hizmeti verilmesinin meslek seçiminde önemli olduğu düşünülmektedir.

13. Dereli F., Kabatas S. Sağlık Yüksekokulu son sınıf öğrencilerinin is bulma endişeleri ve umutsuzluk düzeylerinin belirlenmesi, Yeni Tıp Dergisi, 2009; 26, 31-6.

14. Tekin M. ve Filiz K. Beden Eğitimi ve Spor Yüksekokullarının Antrenörlük Eğitimi ve Spor Yöneticiliği bölümlerinde öğrenim gören öğrencilerin umutsuzluk ve boyun eğici davranış düzeylerinin çeşitli değişkenlere göre incelenmesi, SPORMETRE Beden Eğitimi ve Spor Bilimleri Dergisi,2008; 6:27-37.

15. Ceyhan A.A. Ortaöğretim alan öğretmenliği tezsiz yüksek lisans programına devam eden öğretmen adaylarının umutsuzluk düzeylerinin incelenmesi, Sosyal Bilimler Dergisi, 2004; 91-102.

16. Aktağ I. Alpay D. D. Abant izzet baysal üniversitesi beden eğitimi ve spor yüksekokulunda öğrenim gören öğrencilerinin umutsuzluk düzeyleri. Abant İzzet Baysal Üniversitesi Eğitim Fakültesi Dergisi, 2015; 15:15-24.

17. Ghaderi A.R. Venkatesh Kumar G. \& Sampath, K. Depression, anxiety and stress among the Indian and Iranian students, Journal of the Indian Academy of Applied Psychology, 2009; 35:3-7.

18. Yüksel İ. İşsizlik olgusunun psikolojik boyutu: görgül bir araştırma, Ankara Üniversitesi SBF Dergisi, 2003; 60:260-1. [CrossRef]

19. Şahin C. Eğitim fakültesinde öğrenim gören öğrencilerin umutsuzluk düzeyleri, Selçuk Üniversitesi, Ahmet Keleşoğlu Eğitim Fakültesi Dergisi, 27,2009; 271-86.

20. Çelikel F.Ç., Erkorkmaz Ü. Üniversite öğrencilerinde depresif belirtiler ve umutsuzluk düzeyleri ile ilişkili etmenler, Nöropsikiyatri Arşivi, 2008; 45:122-9.

21. Aytac S., Bayram N. Üniversite gençliğinin is ve eş seçimindeki etkin kriterlerinin analitik hiyerarşi süreci (AHP) ile analizi, Marmara Üniversitesi Sosyal Bilimler Enstitüsü Dergisi, 2001; 16:89-100

22. Tektaş N. Selçuk Üniversitesi Sosyal Bilimler Enstitüsü Dergisi Dr. Mehmet YILDIZ Özel Sayısı 2014, ss. 243-53 